Click www.researchjournal.co.in/online/subdetail.html to purchase.

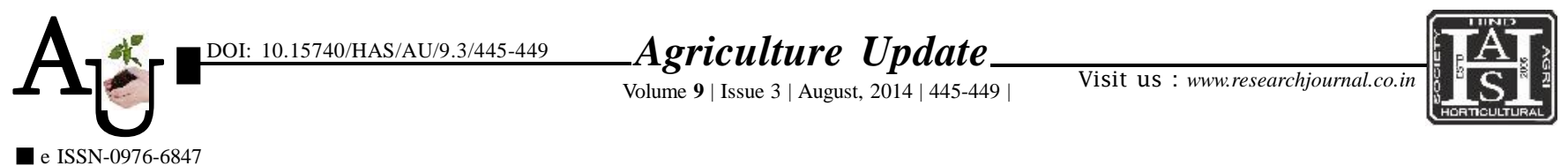

\title{
A Review \\ A review of training needs among rural women
}

\author{
Q RAJDEEP KAUR, CHARANJEET KAUR AND G.S. AULAKH
}

\begin{abstract}
Article Chronicle: Summary : In India, the extension efforts have been largely taken up by the state departments of agriculture Received :

28.06.2014;

Accepted :

25.07.2014

and allied departments and state agricultural universities. Till date, $17 \mathrm{KVKs}$ have been set up at district head quarters all over Punjab for providing different services to the farmers, farm women and rural youth. To improve the financial status of farm/ rural women in Punjab, it was imperative to know the current status of the women in rural areas. Thus, a total sample of two hundred and five female respondents was selected randomly from six blocks of Ferozepur. It was observed that 60 per cent of the respondents from Ghall Khurd block were aware about the existence of KVK in Ferozepur while less than 50 per cent of the respondents from the other blocks were aware of it. A noteworthy observation shows that not even half of the respondents from Ferozepur were aware of the trainings imparted in the Kendra. While taking an overall look into the training needs of the respondents it was observed that training on both stitching and soap and detergent making was the most needed by 93.17 per cent of the respondents. The main constraint in accession to the trainings was 64.88 per cent of the respondents were ignorant regarding the trainings provided at the Kendra. Rest of the barriers were long distance from the Kendra, domestic obligations, financial problem etc.
\end{abstract}

How to cite this article : Kaur, Rajdeep, Kaur, Charanjeet and Aulakh, G.S. (2014). A review of training needs among rural women. Agric. Update, 9(3): 445-449.

\section{KEY WoRdS:}

Block, Knowledge, Needs, Stitching, Training

Author for correspondence :

\section{RAJDEEP KAUR}

Krishi Vigyan Kendra, FEROZEPUR (PUNJAB) INDIA

Email:msrajdeepct@

pau.edu

See end of the article for

authors' affiliations 